\title{
Multi-Attribute Evaluation and Selection of Broiler House for the Low Prevalence of Footpad Lesion
}

\section{-Author(s)}

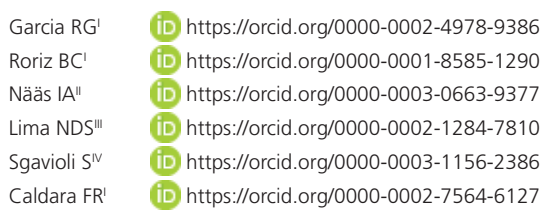

Universidade Federal da Grande Dourados - Faculdade de Ciências Agrárias - Rodovia Dourados-Itahum, Km 12 Cidade Universitaria Unidade II - Dourados, Mato Grosso do Sul, 79804-970 - Brazil.

" UNIP - Engenharia de Produção - Rua Dr. Bacelar, 1212 Vila Clementino, São Paulo, São Paulo 04026-002 - Brazil.

III State University of Campinas - State University of Campinas - Rua Dr. Ruy Vicente de Melo, 1242 Campinas, São Paulo, Brazil.

v Universidade Brasil - Avenida Hilário de Silva Passos, 950 - Parque Universitário, Descalvado-SP CEP 13690-000 - Brazil.

\section{Mail Address}

Corresponding author e-mail address Rodrigo Garófallo Garcia

Av. Indaia, Dourados, Mato Grosso do Sul, 79822-020 - Brazil.

Phone: (5567) 34262198

Email: rodrigogarcia@ufgd.edu.br

\section{EKeywords}

Litter quality, rearing environment, broiler management, footpad dermatitis.

\section{ABSTRACT}

Intensive broiler production requires large flock density, which compromises litter quality and increases the prevalence of footpad lesions. The present study aimed at comparing the incidence of footpad dermatitis of broilers reared in two different rearing environments. Data from two broiler houses were recorded during $42 \mathrm{~d}$. Air temperature and relative humidity; litter moisture, $\mathrm{pH}$, and temperature; footpad surface temperature; and the incidence of footpad lesions was investigated. Litter quality was analyzed in a $2 \times 4$ factorial arrangement, with two house types (dark house or open-sided house) and four rearing phases $(21,28,35$, and $42 \mathrm{~d}$ of growth), with four replicates per treatment using 12 replicates. Four replicates were used for analyzing the air environment data. For the footpad lesion identification, a randomly factorial scheme of recording the surface temperature was built $(2 \times 2)$ using two houses, and the broiler sex using 15 replicates in the grow-out stages. The measures of association (odds ratio and risk ratio) were calculated. The multi-criteria analysis (Analytic Hierarchy Process - AHP) was applied for estimating the house that provided less prevalence of lesions. The field data did not provide enough evidence for selection of a particular house with less incidence of footpad dermatitis. However, when applying the measures of association data, and corresponding literature data to the AHP, there was an indication that the dark-house provided broiler rearing condition that reduced the incidence of footpad lesions.

\section{INTRODUCTION}

Industrial broiler production applies high stocking densities, and some houses may rear up to 30,000 birds. In most tropical countries, broiler houses are built with open sides, which are closed with polypropylene curtains, and are equipped with ventilation fans and fogging systems to provide high-speed tunnel ventilation. This system provides good air movement and removes much of the heat generated inside the house. Some farms rear broilers in dark houses $(\mathrm{DH})$, which are completely closed, and temperature and humidity is controlled by is provided by negative pressure ventilation (exhaustion fans) and cooling pads. Dark-houses $(\mathrm{DH})$ and curtain-sided houses $(\mathrm{CH})$ provide a good thermal environment for intensively-reared broilers during the growout period (Petek et al., 2012; Carvalho et al., 2015). By controlling the temperature and relative humidity inside the houses, broilers farmers can better maintain flock uniformity and provide a more adequate rearing environment (Purswell et al., 2014). Proper ventilation inside the rearing environment leads to good air quality and appropriate litter quality (Garcês et al., 2013; Taira et al., 2014; Lima et al., 2015).

High litter $\mathrm{pH}$ and temperature can cause damaging consequences to broilers (Jacob et al., 2016). The increase in ammonia emission levels 
due to poor litter quality affects the respiratory tract and may cause footpad dermatitis (FPD), hock burns, and breast lesions (Mendes et al., 2012; Carvalho et al., 2015). In addition, poor environment and litter conditions affect broiler welfare, and it may lead to leg conditions (Jonge and Van Trijp, 2013; Tuyttens et al., 2014; Souza et al., 2015). The severity of the lesions caused by poor litter is correlated with the environmental rearing conditions (Hashinomoto et al., 2011; Jacob et al., 2016).

After the breast and wings, broiler feet are the third most important economic as they account for the third largest demand for exports (Jacob et al., 2016). An important management criterion to broiler growers is the identification of broiler houses with high FPD prevalence, as this information may allow applying measures to mitigate possible losses during live production.

The multi-attribute/criterion analysis provides an appropriate evaluation for this particular scenario (Saaty, 1980; Almeida Paz et al., 2010; Garcia et al., 2012). Among the available multi-attribute approaches, the analytic hierarchy process (AHP) allows combining different types of criteria in a multi-level decision-making structure to obtain a single score for each alternative with a specific characteristic (Pilecco et al., 2012; Nääs et al., 2015). The purpose of the process is to provide a vector of weights expressing the relative importance of the alternatives for each criterion. The adopted scale of relevance was defined according to Saaty (1980), using a 1 to 9 scale for pairwise comparison. These pairwise comparisons yield a reciprocal $(n \times n)$ matrix $A$, where aii $=1$ (diagonal elements) and aji $=1 / a i j$.

The present study aimed at comparing two different broiler rearing environments, which provided a combination of different factors, and to study the effect of these factors on the incidence of footpad dermatitis.

\section{MATERIAL AND METHODS}

The field trial was carried out in the Southwestern region of Brazil (longitude 54 $11^{\prime} 6^{\prime \prime} \mathrm{W}$ and latitude $23^{\circ} 28^{\prime} 26^{\prime \prime}$ S). Six dark housed (DH) and six curtainsided broiler house $(\mathrm{CH})$ were evaluated. DH houses (15-m wide, 150-m long and 3.2-m high) were equipped with forced ventilation by exhaustion fans (12 fans with an air flow of $580 \mathrm{m3} \mathrm{s}-1$ ), a highpressure fogging system, and internal masonry walls painted black. CH houses (15-m wide, 150-m long and 3.2-m high) were equipped with forced ventilation by exhaustion fans (11 fans with an air flow of $450 \mathrm{~m} 3$ s-1), a low-pressure fogging system, and sides closed off with yellow polypropylene curtains $(0.17-\mathrm{mm}$ thickness). The studied broiler houses were all on the same farm and oriented in the East-West direction.

A total of 31,500 one-d-old broiler chicks (half males and the half females) were reared in each house for $42 \mathrm{~d}$. The adopted flock density was 14 birds $m-2$, and birds were reared on re-used rice husks litter (10-cm deep). On the $27 \mathrm{~d}$ of the grow-out, the litter was revolved (which is a standard broiler house management in Brazil to reduce litter compaction), and hydrated lime $(0.5 \mathrm{~kg} \mathrm{~m}-2)$ was spread on and mixed with the litter. The houses were virtually divided into three quadrants with the purpose of collecting the samples of the variables equally, and the recording was done in the geometric center of each quadrant.

Environmental temperature and relative humidity, and litter temperature were recorded from 8:00h to 10:00h. Litter samples of litter were collected and conditioned in plastic bags to determine their moisture and $\mathrm{pH}$ in the laboratory. The footpad of 20 birds (10 males and 10 females) as also examined during the same period. All data were recorded on d 21, 28, 35 , and 42 of the grow-out period of the flock in three places per quadrant near the geometric center. The experimental procedure was approved by the Ethics Committee of the Federal University of Grande Dourados (protocol n. 012/2015).

Rearing environment data (air temperature and relative humidity) were recorded using a portable thermal-hygrometer (ICEL model HT-7020, Prismacom Inc., Rua Vaticano 269, Brazil) with the precision of \pm $0.01^{\circ} \mathrm{C}$. Litter temperature at $5-\mathrm{cm}$ depth was recorded using a digital probe thermometer (AKSO, AK05, Akso Inc., São Paulo, Brazil) with the accuracy of $\pm 0.5^{\circ} \mathrm{C}$ and a range of -10 to $100{ }^{\circ} \mathrm{C}$. Three samples of litter per quadrant were collected and placed in plastic bags and placed inside a cooler for subsequent analyses. Litter $\mathrm{pH}$ was determined using a $\mathrm{pH}$ meter (Hanna, HI-2210, Hanna Inst., São Paulo, Brazil) with precision of $\pm 0.01 \mathrm{pH}$ and range of -2.0 to 16.0 . Litter samples were dilluted in distilled water $(25 \mathrm{~g}$ litter per $70 \mathrm{~mL}$ distilled water) and homogenized (Camargo and Valadares, 1980). Litter moisture (LM) was determined placing a 100-g sample in a drying oven for 12 hours at $105^{\circ} \mathrm{C}$, as suggested by the Official Methods of Analysis (Helrich, 1990). LM value was calculated using Equation 1.

$$
\operatorname{LM}(\%)=\frac{(\text { initial weight }- \text { final weight })}{\text { initial weight } \times 100}
$$

Eq. 1 
Garcia RG, Roriz BC, Nääs IA, Lima NDS, Sgavioli S, Caldara FR
Multi-Attribute Evaluation and Selection of Broiler House for the Low Prevalence of Footpad Lesion
Ten broilers (five males and five females) were randomly chosen in each quadrant, and their footpad surface temperature was determined using thermal images from a digital thermal camera (Testo $880^{\circledR}$, Testo Inst., Lenzkirch, Germany) with the accuracy of $\pm 0.2{ }^{\circ} \mathrm{C}$ within the spectrum of $7.5-13 \mu \mathrm{m}$ ). The emissivity adopted was 0.95 (Nääs et al., 2010). Three points within the broiler footpad image were selected and processed using the Testo thermal imager software (Testo IRSoft ${ }^{\circledR}$, version 2.3, Testo Inst., Lenzkirch, Germany). Footpad surface temperature was analyzed as suggested by Jacob et al. (2016) and Roberto and Souza (2014).

Footpad lesion was scored using the scale of Hashinomoto et al. (2011) (Figure 1), where $0=$ no lesions, $1=$ lesion in $50 \%$ of the footpad area, $2=$ lesion in $50-100 \%$ of the footpad area, and $3=$ lesion in $100 \%$ of the footpad area and in surrounding areas.
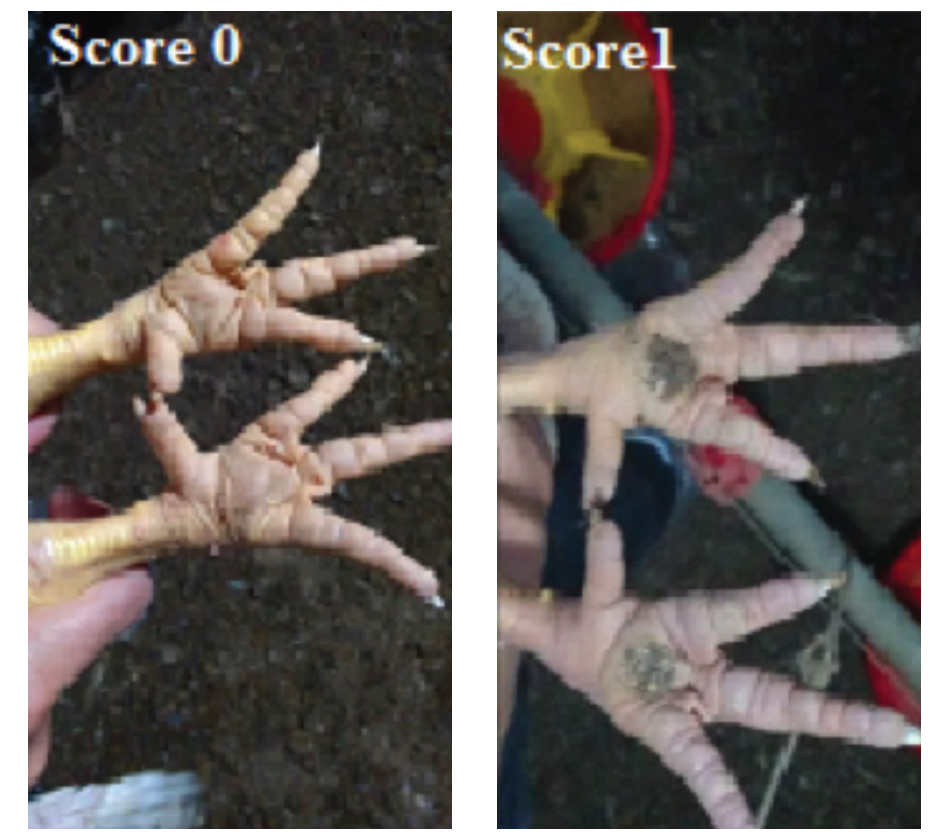

Figure $\mathbf{1}$ - The degree of the lesion in broiler footpad ( 0 for sound footpad, 1 for footpad with less than $50 \%$ lesion, 2 for footpad with an injury between 50 to $100 \%$, and 3 for footpadand digits with lesions; Hashimoto et al., 2011).

between the variables. Means were compared by Tukey's test at a 95\%confidence interval. The software Assistat (Silva \& Azevedo, 2016) was used.

The incidence of footpad lesions was analyzed using the scores suggested by Hashimoto (2011). The measures of association (odds ratio and risk ratio) were calculated using logistic regression and Fisher's exact probability test for all four grow-out phases $(21,28$, 35 , and 42 d) at $95 \%$ confidence interval. The online software VassarStats (2016) was used.

Analytical Hierarchy Process (AHP) was applied for the multi-attribute/criteria analysis (Almeida Paz
Litter quality was analyzed according to a completely randomized experimental design in a $2 \times 4$ factorial arrangement was applied, consisting of two house types (DH and $\mathrm{CH}$ ) and four grow-out phases $(21,28$, 35 , and $42 \mathrm{~d}$ ), with 12 replicates per treatment, totaling 96 experimental units. The same experimental design was applied to analyze internal house environment (air temperature and relative humidity), but using four replicates, totaling 32 experimental units. Footpad surface temperature was analyzed by randomly selecting points in the thermal image ob both feet (right and left) and applying a $2 \times 2$ arrangement with two house types (DH or CH) $x$ sex (female or male) with 15 replicates in each of the four phases of growth (21, 28,35 , and $42 \mathrm{~d}$ of grow-out).

\section{Statistical analysis}

After checking the normality of the data Two-way ANOVA was applied to verify if there is an interaction
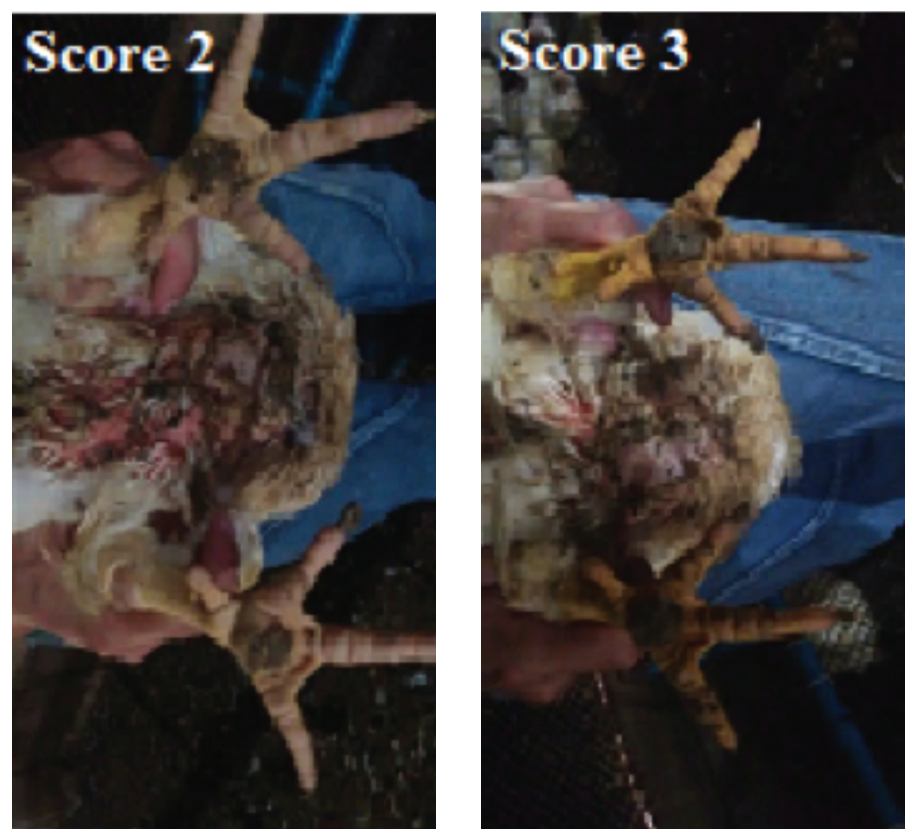

et al., 2010; Garcia et al., 2012). The criteria were litter quality (litter temperature and $\mathrm{pH}$ ), rearing environment (ambient temperature and relative humidity), broiler age $(21,28,35$, and $42 \mathrm{~d})$, and sex (female and male). All criteria were considered using the results of the field experiment accurately compared, taking into account the statistical analysis and the association measurements. Information from the database set found in current references in Table 1 were also used to support specific attributes. The online software BPMSG (2017) was used to calculate the weight matrices. 
Table 1 - Information from the database set found in current literature used to help weigh the attributes for processing the Analytic Hierarchy Process (AHP).

\begin{tabular}{|c|c|c|c|c|}
\hline \multirow[b]{2}{*}{ Author } & \multicolumn{4}{|c|}{ Studied attributes } \\
\hline & Litter quality & Rearing environment & Broiler age & Broiler sex \\
\hline Pagazaurtundua andWarriss (2006) & $x$ & $x$ & - & - \\
\hline Eichner et al. (2007 & $\mathrm{x}$ & $\mathrm{x}$ & $x$ & - \\
\hline Nagaraj et al. (2007) & $x$ & $x$ & - & - \\
\hline Nowaczewski et al. (2007) & $x$ & $x$ & - & $x$ \\
\hline Bilgili et al. (2009) & $x$ & $x$ & - & - \\
\hline Almeida Paz et al. (2010) & $x$ & $x$ & $x$ & $x$ \\
\hline Shepherd et al. (2010) & $x$ & $x$ & - & - \\
\hline Hashimoto et al. (2011) & - & $x$ & $x$ & - \\
\hline El-Wahab et al. (2012) & $x$ & $x$ & $x$ & - \\
\hline Garcia et al. (2012) & $x$ & $x$ & $x$ & $x$ \\
\hline Mendes et al. (2012) & $x$ & $x$ & $x$ & - \\
\hline Pilecco et al. (2012) & $\mathrm{x}$ & $\mathrm{x}$ & $x$ & $x$ \\
\hline Almeida Paz et al. (2013) & $x$ & $x$ & - & $x$ \\
\hline Garcês et al. (2013) & $x$ & $x$ & $x$ & - \\
\hline Martins et al. (2013) & $x$ & $x$ & $x$ & - \\
\hline Sarica et al. (2014) & $x$ & $x$ & $x$ & - \\
\hline Taira et al. (2014) & $x$ & $x$ & $x$ & - \\
\hline Jacob et al. (2016) & $x$ & $x$ & $x$ & $x$ \\
\hline Garcês et al. (2017) & $x$ & $x$ & $\mathrm{x}$ & - \\
\hline
\end{tabular}

\section{RESULTS AND DISCUSSION}

Higher litter $\mathrm{pH}(p<0.05)$ was measured on $\mathrm{d} 28$ and 35 than on the other phases ( 21 and $42 \mathrm{~d}$ ), and lower in the final rearing week in $\mathrm{DH}$ compared with $\mathrm{CH}$. Mean litter $\mathrm{pH}$ values were higher $(p<0.05)$ in $\mathrm{CH}$ than in $\mathrm{DH}$ (Table 2). Mean litter moisture values were similar between $\mathrm{CH}$ and $\mathrm{DH}(p>0.05)$, and significantly decreased $(p<0.05)$ with grow-out phase in $\mathrm{CH}$. An interaction between house type and broiler age was detected for litter $\mathrm{pH}$ and humidity results, indicating that house type influenced the internal environment and litter quality as a function of bird age (Table 2). In the current literature, several authors identified that litter quality was a primary concern in the prevalence of FPD (Eichner et al., 2007; Nagaraj et al., 2007;
Nowaczewski et al., 2011; El-Wahab et al., 2012; Garcês et al., 2013).

The differences in litter $\mathrm{pH}$ related to broiler age is possibly due to the litter management. The typical procedure of adding hydrated lime and revolving the litter on $\mathrm{d} 27 \mathrm{~d}$ of the grow-out likely influenced the decrease in the $\mathrm{pH}$ in the following days. The high litter $\mathrm{pH}$ in the $\mathrm{CH}$ may indicate that birds reared in that environment may potentially have higher pododermatitis incidence during the final stage of production. However, litter moisture was close to $30 \%$ in both houses, leading to similar litter quality in both houses during the early stages of the grow-out. High litter moisture favors microbial replication and ammonia emissions, deteriorating air quality. Lima et al. (2015) found higher litter $\mathrm{pH}$ and temperature values in $\mathrm{DH}$ than in $\mathrm{CH}$, resulting in higher ammonia emissions,

Table 2 - Average values of litter quality ( $\mathrm{pH}$ and moisture) in the studied houses during the grow-out days.

\begin{tabular}{|c|c|c|c|c|c|}
\hline \multirow[b]{2}{*}{ Factor } & \multicolumn{4}{|c|}{ Age of broilers (day) } & \\
\hline & 21 & 28 & 35 & 42 & \\
\hline House & \multicolumn{4}{|c|}{ Litter $\mathrm{pH}$} & Mean \\
\hline $\mathrm{DH}$ & $8.1 \mathrm{bB}$ & $9.1 \mathrm{aA}$ & $9.0 \mathrm{aA}$ & $8.2 b C$ & $8.2 b$ \\
\hline $\mathrm{CH}$ & $9.0 \mathrm{aB}$ & 9.2aAB & 8.0bAB & $9.0 \mathrm{aA}$ & $9.1 \mathrm{a}$ \\
\hline \multicolumn{6}{|c|}{$C V(\%)=2$} \\
\hline \multicolumn{6}{|c|}{ Litter moisture(\%) } \\
\hline $\mathrm{DH}$ & $29.0 a A B$ & $32.1 \mathrm{aA}$ & $27.0 \mathrm{aB}$ & $27.1 \mathrm{aB}$ & $29.1 \mathrm{a}$ \\
\hline $\mathrm{CH}$ & $31.1 \mathrm{aA}$ & $29.2 \mathrm{bA}$ & $28.2 \mathrm{aAB}$ & $25.1 \mathrm{aB}$ & $28.2 \mathrm{a}$ \\
\hline
\end{tabular}

Means followed by the same letter (lowercase in the column and columnand uppercase in the line) did not differ by Tukey test ( $\mathrm{p} \geq 0.05)$. CV $=$ coefficient of variation. $\mathrm{DH}=$ dark house; $\mathrm{CH}=$ curtain-side house. 
and, therefore, worse air quality. Bilgili et al. (2009), evaluating the influence of litter substrates on FPD severity of, determined high FDP incidence in 42-d-old broilers reared on high-moisture litter. Therefore, it is likely that the high litter moisture in $\mathrm{DH}$ induced the FPD observed in 42-d-old broilers in the present study.

Internal air temperature was not different ( $p>0.05)$ between $\mathrm{DH}$ and $\mathrm{CH}$ (Table 3). Mean air temperatures were higher $(p<0.05)$ on $d 21,28$ and 42 than on $d$ $35 \mathrm{~d}$. On the other hand, higher mean RH ( $p>0.05)$ was recorded in $\mathrm{CH}$ than in $\mathrm{DH}$. Relative to broiler age, the highest $\mathrm{RH}$ were determined when broilers were 35 -d-old (75\%), and the lowest on d 28 (53.1\%).

An efficient ventilation system provides fresh air to the birds and also improves litter quality, as it reduces litter moisture. The use of minimal ventilation systems increases the removal of noxious gases, which also increase the prevalence of FPD in broilers (Czarick \& Fairchild, 2007). The combined effect of temperature, relative humidity, air velocity, and particle and microorganism concentrations in the air determine the air quality within the rearing environment (Garcês et al., 2017). A plausible explanation for a higher occurrence of FPD lesions in 42-d-old males reared in $\mathrm{DH}$ is the increase of air relative humidity as birds grew, impairing litter quality.

Footpad surface temperature results are presented in Table 4. No differences were observed on d 21. On d 28 , birds reared in $\mathrm{DH}$ presented higher mean surface temperature in the right footpad $\left(31.0^{\circ} \mathrm{C}\right)$ than those in $\mathrm{CH}\left(30.1^{\circ} \mathrm{C}\right)$, as well as in the left footpad, of $32.1^{\circ} \mathrm{C}$ in $\mathrm{DH}$-reared broilers and $30.1{ }^{\circ} \mathrm{C}$ in birds housed in

Table 3 - Mean air temperature $\left({ }^{\circ} \mathrm{C}\right)$ and relative humidity $(\%)$ at the different houses for the studied broiler ages.

\begin{tabular}{|c|c|c|c|c|c|}
\hline \multirow{2}{*}{ Factor } & \multicolumn{4}{|c|}{ Age of broilers (day) } & \multirow[b]{2}{*}{ Mean } \\
\hline & 21 & 28 & 35 & 42 & \\
\hline House & \multicolumn{4}{|c|}{ Air temperature $\left({ }^{\circ} \mathrm{C}\right)$} & \\
\hline $\mathrm{DH}$ & 26.2 & 27.1 & 24.2 & 25.3 & $26.1 \mathrm{a}$ \\
\hline $\mathrm{CH}$ & 26.1 & 26.2 & 24.1 & 27.0 & $26.2 \mathrm{a}$ \\
\hline \multicolumn{6}{|c|}{$\mathrm{CV}(\%)=2.5$} \\
\hline \multicolumn{6}{|c|}{ Air relative humidity (\%) } \\
\hline $\mathrm{DH}$ & $61.0 \mathrm{aB}$ & $53.1 \mathrm{aC}$ & $75.0 \mathrm{aA}$ & $55.1 \mathrm{bBC}$ & $61.2 \mathrm{~b}$ \\
\hline $\mathrm{CH}$ & $65.0 \mathrm{aC}$ & $36.1 \mathrm{bD}$ & $74.2 \mathrm{aB}$ & $82.2 \mathrm{aA}$ & $64.1 \mathrm{a}$ \\
\hline
\end{tabular}

Means followed by the same letter (lowercase in the column and columnand uppercase in the line) did not differ by Tukey test $(p \geq 0.05)$. $\mathrm{CV}=$ coefficient of variation. $\mathrm{DH}=$ dark house; $\mathrm{CH}=$ curtain-side house.

$\mathrm{CH}$. When birds were 35 days old, lower mean left footpad surface temperature was measured in $\mathrm{DH}$ $\left(30.1^{\circ} \mathrm{C}\right)$ than $\mathrm{CH}\left(30.2^{\circ} \mathrm{C}\right)$. At 42 days of age, there was no influence of housing type on footpad surface temperature. However, males presented higher average footpad surface temperature $\left(34.0^{\circ} \mathrm{C}\right)$ than females in $\mathrm{DH}\left(32^{\circ} \mathrm{C}\right)$, both in the right footpad (males $=34^{\circ} \mathrm{C}$ and females $=32.1^{\circ} \mathrm{C}$ ) and in the left footpad (males $=34.0^{\circ} \mathrm{C}$ and females $=33.2^{\circ} \mathrm{C}$ ). Surface temperature has been applied to determine the presence of lesions and heat stress (Nääs et al., 2010; Nascimento et al., 2014). The identification of FPD using footpad surface temperature was previously used by Jacob et al. (2016). These authors found a high correlation between the increase in footpad surface temperature as the lesion develops, indicating an inflammatory process. As the lesion progresses, tissues become necrotic, and surface temperature decreases.

At $21 \mathrm{~d}$ of age, the proportion of broilers with FPD scores 1 to 3 was 40\% (12/30), and 60\% (18/30) with score 0 in $\mathrm{DH}$, and $93 \%$ (28/30) with scores 1 to 3 , and $7 \%$ with score 0 in $\mathrm{CH}$. The results of the measures of association did not detect any association between broiler sex and FPD incidence in 21-d-old broilers either in $\mathrm{DH}$ or $\mathrm{CH}$ (Table 5). In addition, the factor house ( $\mathrm{DH}$ vs. $\mathrm{CH}$ ) did not influence FPD incidence at this age, with odds ratio $(O R)$ and risk ratio $(R R)$ of $O R=0.05$ and $R R=0.43$, respectively. The risk ratio $(R R)$, also called relative risk, compares the risk of a health event (disease, injury, risk factor, or death) between one group exposed to the risk and a non-exposed group (Thompson et al., 1998). However, when Fisher's exact probability test was applied, DH-reared birds presented lower incidence and lower FPD on d 21 ( $p=0.00001)$ (Table 5).

At $28 \mathrm{~d}$ of age, the proportion of birds presenting FPD scores 1 to 3 was 70\% (21/30) and 30\% score $0(9 / 30)$ in $\mathrm{DH}$. In $\mathrm{CH}, 93 \%$ (28/30) of the broilers had 1-3 FDP scores, and 7\% score 0 (2/30). A low association $(R R=0.73 ; O R=0.91)$ was determined between FDP presence and broiler sex, whereas in $\mathrm{CH}$, no association between sex and the presence of FDP lesions was detected $(R R=1.0$ and $O R=1.0)$. Using Fisher's exact probability test, $\mathrm{DH}$ differed from $\mathrm{CH}$ ( $p$ 
Table 4 - Right footpad surface temperature (RFST) and left (LFST) in the different broiler houses.

\begin{tabular}{|c|c|c|c|c|c|c|}
\hline \multicolumn{7}{|c|}{$21 \mathrm{~d}$ old } \\
\hline & \multicolumn{3}{|c|}{ RFST } & \multicolumn{3}{|c|}{ LFST } \\
\hline House & M & $\mathrm{F}$ & Mean & M & $\mathrm{F}$ & Mean \\
\hline $\mathrm{DH}$ & 32.0 & 32.1 & $32.2 \mathrm{a}$ & 32.1 & 32.1 & $32.2 \mathrm{a}$ \\
\hline $\mathrm{CH}$ & 33.1 & 32.2 & $33.1 \mathrm{a}$ & 33.2 & 32.2 & $32.2 \mathrm{a}$ \\
\hline \multicolumn{7}{|c|}{$\mathrm{SD}(\mathrm{RFST})=2 ; \mathrm{SD}(\mathrm{LFST})=2 ; \mathrm{CV}(\mathrm{RFST} ; \%)=6 ; \mathrm{CV}(\mathrm{RFST} ; \%)=6$} \\
\hline \multicolumn{7}{|c|}{$28 \mathrm{~d}$ old } \\
\hline $\mathrm{DH}$ & 32.2 & 31.1 & $31.0 \mathrm{a}$ & 32.2 & 32.1 & $32.1 \mathrm{a}$ \\
\hline $\mathrm{CH}$ & 30.0 & 30.2 & $30.1 \mathrm{~b}$ & 30.0 & 30.1 & $30.1 \mathrm{~b}$ \\
\hline \multicolumn{7}{|c|}{$\mathrm{SD}(\mathrm{RFST})=2 ; \mathrm{SD}(\mathrm{LFST})=2 ; \mathrm{CV}(\mathrm{RFST} ; \%)=7 ; \mathrm{CV}(\mathrm{RFST} ; \%)=7$} \\
\hline \multicolumn{7}{|c|}{ ( } \\
\hline $\mathrm{DH}$ & 30.0 & 30.1 & $30.1 \mathrm{a}$ & 30.2 & 29.3 & $29.2 b$ \\
\hline $\mathrm{CH}$ & 30.0 & 30.2 & $30.2 \mathrm{a}$ & 31.0 & 30.0 & $31.3 \mathrm{a}$ \\
\hline \multicolumn{7}{|c|}{$\mathrm{SD}(\mathrm{RFST})=2 ; \mathrm{SD}(\mathrm{LFST})=2 ; \mathrm{CV}(\mathrm{RFST} ; \%)=6 ; \mathrm{CV}(\mathrm{RFST} ; \%)=6$} \\
\hline \multicolumn{7}{|c|}{ ( } \\
\hline $\mathrm{DH}$ & 34.0 & 32.1 & $33.1 \mathrm{a}$ & 34.0aA & $32.1 \mathrm{aB}$ & $33.2 \mathrm{a}$ \\
\hline $\mathrm{CH}$ & 33.2 & 33.1 & $33.2 \mathrm{a}$ & 33.2aA & 33.2aA & $33.1 \mathrm{a}$ \\
\hline
\end{tabular}

Means followed by the same letter (lowercase in the column and columnand uppercase in the line) did not differ by Tukey test ( $p \geq 0.05)$. For the interaction at the $42 \mathrm{~d}$ of growth: column are in lowercase and lines are in uppercase. SD = Standard deviation. CV = coefficient of variation.

$=0.041)$, with lower risk of FPD incidence $(R R=0.17$ and $\mathrm{OR}=0.75)$ in $\mathrm{DH}$ (Table 5).

At the phase of $35 \mathrm{~d}$ old the proportion of broilers with scores 1 to 3 was $57 \%$ (17/30) and score 0 was $7 \%(2 / 30)$ in $\mathrm{DH}$. Considering the factor sex no association was found between the bird's sex and the housing alternative, and the risk was low in both tested houses. When using Fisher exact probability test for the factor house (DH vs. $\mathrm{CH}$ ), the incidence of FPD was lower in $\mathrm{DH}(p=0.002$ (Table 5).

At $42 \mathrm{~d}$ of age, the proportion of DH-reared birds with no FPD lesion (score 0 ) was $57 \%(17 / 30)$ and $43 \%$ $(13 / 30)$ scores $1-3$, whereas in the $\mathrm{CH}, 13 \%(4 / 30)$ birds had no FDP lesions (score 0 ) and 87\% (26/30) FPD scores 1-3. There was a significant effect of the factor sex (male vs. female) during the last stage of rearing, when FPD occurrence was 1.31-fold higher in males than in females. The relative risk of males presenting FDP were 1.71 times higher in those reared in $\mathrm{DH}$ than in $\mathrm{CH}$. Fisher's exact test result showed a significant association ( $p=0.0009)$ between house type and FPD incidence on d 42 of the grow-out period, consistent with the lower rate of footpad lesions observed in $\mathrm{DH}$-reared broilers relative to $\mathrm{CH}$. A plausible explanation for a higher occurrence of FPD in 42-d-old males compared with females is the combination of higher males weight gain and the better-controlled environment in HD. Studies have shown that footpad lesions gradually progress as the bird grows (Sarica et al., 2014; Shepherd and Fairchild, 2010). Hashinomoto et al. (2011) found that 7-d-old broilers already present subclinical footpad lesions, which increase in area and become more severe as the birds age. At $21 \mathrm{~d}$ of age, the macroscopic changes in the footpad are characterized by the presence of crusts in the footpad and digit articulations (Jacob et al., 2016). Litter quality and material may also cause footpad lesions (Bilgili et al., 2009; Shepherd \& Fairchild, 2010).

The Analytic Hierarchy Process (AHP) was applied due to the high complexity and the multi-attribute factors interfering in the analysis of the causes of FPD in broilers during the grow-out stages. Published literature results were used to complement the data of the current study for the AHP (Table 1). The output results of the present experiment were also used as input to determine the weights applied in AHP calculations. The AHP results suggest that broilers reared in $\mathrm{DH}$ showed lower incidence of footpad dermatitis (0.61) than $\mathrm{CH}$ (0.39), as shown in Figure 2. The source criteria that led to these findings were litter quality and rearing environment of DH (Figure 3). The calculated matrix was consistent, and the consistency index $(\mathrm{Cl}, \mathrm{Eq} 2)$ values were adequate. In all tested comparisons, the consistency ratio $(C R)$ compared to the consistent index (RI) $(\mathrm{CR}=\mathrm{Cl} / \mathrm{RI})$ was acceptable $(\leq 0.1)$.

$$
\mathrm{Cl}=\frac{\lambda \max -\mathrm{n}}{\mathrm{n}-1}
$$

The overlapping of the applied criteria and weights are shown in the graph in Figure 3, indicating higher weights for litter quality and rearing environment in $\mathrm{DH}$ than in $\mathrm{CH}$. The prevalence of FPD is highly correlated with rearing environment and litter quality (Garcês et al., 2013; Garcês et al., 2017). As broilers age, they become 
Garcia RG, Roriz BC, Nääs IA, Lima NDS, Sgavioli S, Caldara FR

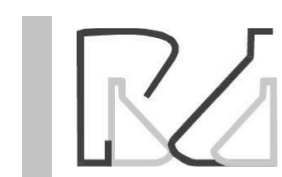

Multi-Attribute Evaluation and Selection of Broiler House for the Low Prevalence of Footpad Lesion

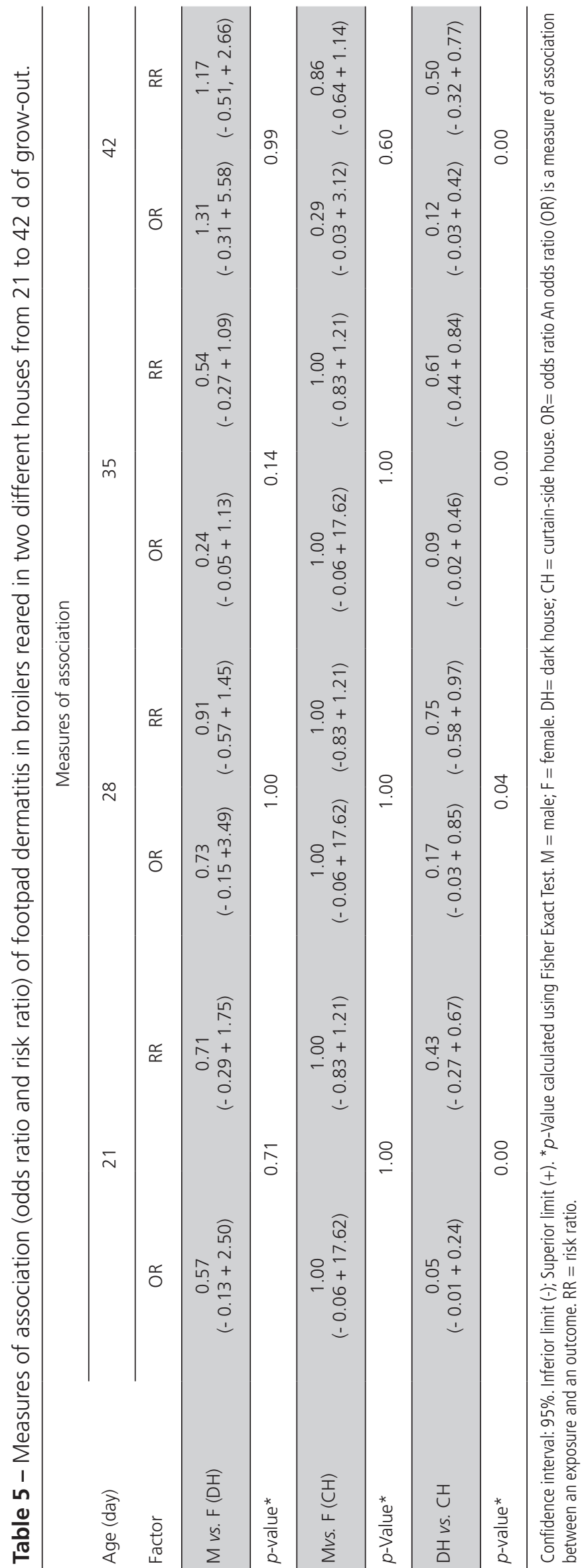

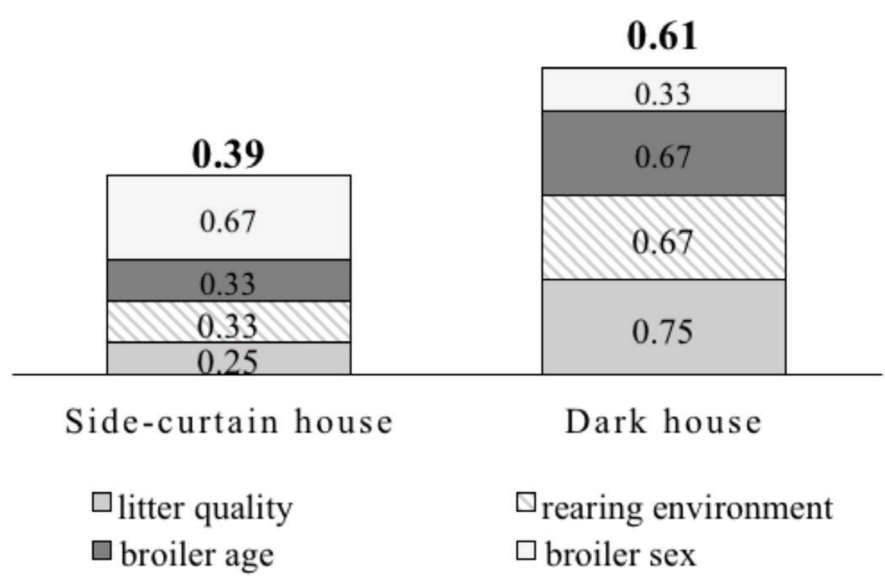

Figure $\mathbf{2}$ - Total weight of the alternatives (dark-house, DH and side-curtain house, $\mathrm{CH}$ ) comparison and the assessment of the calculated weight of each criterion within each tested housing alternative for abroiler house with less incidence of footpad dermatitis.

heavier, increasing the incidence of FPD, as stated by Hashimoto et al. (2011) and Giloh et al. (2012).

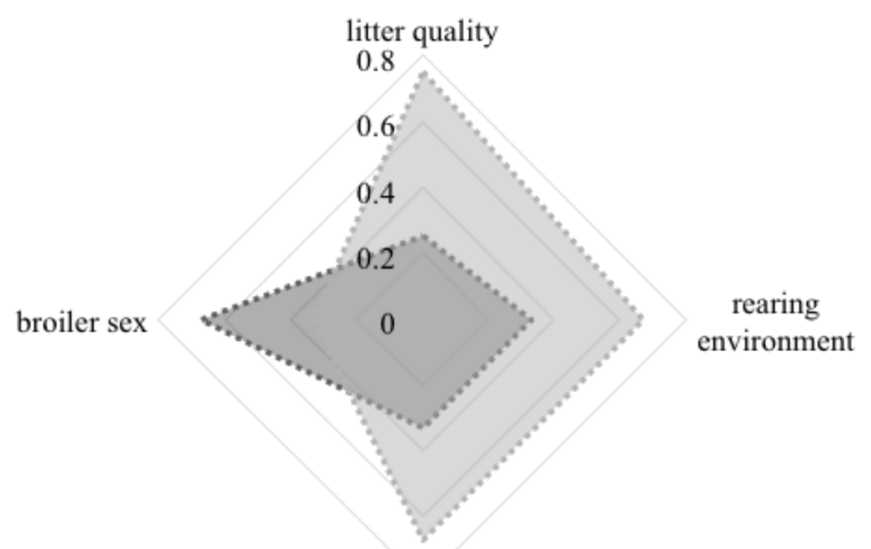

broiler age

\$Side-curtain house thark house

Figure 3 - Profile of the weight distribution of the criteria used as input in the Analytic hierarchy process (AHP) calculation to select abroiler house in the tested alternatives of the dark-house $(\mathrm{DH})$ and the curtain-side house $(\mathrm{CH})$.

Determining house types where the prevalence of footpad dermatitis is lower is a complex task. The multi-factorial scope of this condition indicates that each variable in each broiler house type have different influence on the incidence and severity of FPD. The results of the current study suggest that broilers reared in dark houses have lower risk of presenting FPD.

\section{ACKNOWLEDGMENTS}

This study was carried out with the financial support of the Federal University of Grande Dourados (UFGD). The authors would also like to thank the Coordination for the Improvement of Higher Education Personnel (CAPES) for granting the scholarships. 


\section{REFERENCES}

Almeida Paz ICL, Garcia RG, Bernardi R, Nääs IA, Caldara FR, Freitas LW, Seno LO, Ferreira VMOS, Pereira DF, Cavichiolo F. Selecting appropriate bedding to reduce locomotion problems in broilers. Revista Brasileira de Ciência Avícola/Brazilian Journal of Poultry Science 2010; 12: 189 195.

Almeida Paz ICL, Garcia RG, Bernardi R, Seno LO, Nääs IA, Caldara FR. Locomotor problems in broilers reared on new and re-used litter. Italian Journal of Animal Science 2013; 12: 275-279.

Bilgili SF, Hess JB, Blake JP, Macklin KS, Saenmahayak B, Sibley JL. Influence of bedding material on footpad dermatitis in broiler chickens. The Journal of Applied Poultry Research 2009; 18: 583-589.

BPMSG. 2017. Online software. Available at: http://bpmsg.com/academic/ ahp.php. Accessed on Mar 1, 2017.

Carvalho RH, Soares AL, Grespan M, Spurio RS, Coró FA, Oba A, Shimokomaki $\mathrm{M}$. The effects of the dark house system on growth, performance and meat quality of broiler chicken. Animal Science Journal 2015; 86 189-193.

Czarick M, Fairchild B. Minimum Ventilation Rates. Poultry Housing Tips 2007; v. 19, n.1, 1-4.

Eichner G, Vieira SL, Torres CA, Coneglian JLB, Freitas DM, Oyarzabal O. A litter moisture and footpad dermatitis as affected by diets formulated on an all-vegetable basis or having the inclusion of poultry by-product. The Journal of Applied Poultry Research 2007; 16: 344-350

El-Wahab AA, Visscher CF, Beineke A, Beryerbach M, Wolken S, Reperant JM, Kamphues J. Investigations on diet composition, litter quality and experimental infection on the severity of foot pad dermatitis in young turkeys housed with or without floor heating. Lohman Information 2012; 47: 344-350.

Garcês A, Afonso SMS, Chilundo A, Jairoce CTS. Evaluation of different litter materials for broiler production in a hot and humid environment: 1. Litter characteristics and quality. The Journal of Applied Poultry Research 2013; 22: 168-176.

Garcês AP, Afonso SMS, Chilundo A, Jairoce CT. Evaluation of different litter materials for broiler production in a hot and humid environment: 2. Productive performance and carcass characteristics. Tropical Animal Health and Production 2017; 49: 369-374, 2017.

Garcia RG, Almeida Paz ICL, Caldara FR, Nääs IA, Pereira DF, Ferreira VMOS. Selecting the most adequate bedding material for broiler production in Brazil. Revista Brasileira de Ciência Avícola/Brazilian Journal of Poultry Science 2012; 14: 121-127.

Giloh M, Shinder D, Yahav S. Skin surface temperature of broiler chickens is correlated to body core temperature and is indicative of their thermoregulatory status. Poultry Science 2012; 91: 175-188.

Hashimoto S, Yamazaki K, Takeshi OBI, Takase K. Footpad dermatitis in broiler chickens in Japan. Journal of Veterinary Medical Science 2011; 73: 293-297.

Helrich K. Official Methods of Analysis. Association of Official Analytical Chemists Inc., Arlington, 15th ed., p. 935-937. 1990.

Jacob FG, Baracho MD, Nääs IA, Souza R, Salgado DD. The use of infrared thermography in the identification of pododermatitis in broilers. Engenharia Agrícola 2016; 36: 253-259.

Jonge J, Van Trijp HC. The impact of broiler production system practices on consumer perceptions of animal welfare. Poultry Science 2013; 92 : 3080-3095

Lima NDS, Garcia RG, Nääs IA, Caldara FR, Ponso R. Model-predicted ammonia emission from two broiler houses with different rearing systems. Scientia Agricola 2015; 72: 393-399.

Martins RS, Hötzel MJ, Poletto R. Influence of in-house composting of reused litter on litter quality, ammonia volatilisation and incidence of broiler footpad dermatitis. British Poultry Science 2013; 54: 669-676.
Mendes AS, Paixão SJ, Marostega J, Restelatto R, Oliveira PAV, Possent JC. Measurement of locomotor problems and pad lesions in broilers. Archivos de Zootecnia 2012; 61: 217-228.

Nääs IA, Romanini CEB, Neves DP, Nascimento GR, Vercellino RA. Broiler surface temperature distribution of 42 day old chickens. Scientia Agricola 2010; 67: 497-502.

Nääs IA, Mollo Neto M, Vendrametto O, Canuto SA. Comparative analysis of different meat traceability systems using multiple criteria and a social network approach. Engenharia Agrícola 2015; 35: 340-349.

Nagaraj M, Wilson CAP, Saenmahayak B, Hess JB, Bilgili SF. Efficacy of a litter amendment to reduce pododermatitis in broiler chickens. The Journal of Applied Poultry Research 2007; 16: 255-261.

Nascimento ST, Silva IJO, Maia ASC, Castro AC, Vieira FMC. Mean surface temperature prediction models for broiler chickens - a study of sensible heat flow. International Journal of Biometeorology 2014; 58: 195-201.

Nowaczewski S, Rosi冈ski A, Markiewicz M, Kontecka H. Performance, footpad dermatitis and hemoglobin saturation in broiler chickens kept on different types of litter. Arch Geflügelk 2011; 75: 132-139.

Pagazaurtundua A, Warriss PD. Levels of foot pad dermatitis in broiler chickens reared in 5 different systems. British Poultry Science 2006; 47: 529-532.

Petek M, Dikmen S, O凶an MM. Performance analysis of a two-stage pad cooling system in broiler houses. Turkish Journal of Veterinary and Animal Sciences 2012; 36: 21-26.

Pilecco M, Almeida Paz ICL, Tabaldi LA, Nääs IA, Garcia RG, Caldara FR, Andreia GO. Multi-criteria analysis of the influence of rearing, equipment, and catching management practices on the Incidence of back scratches in broilers. Revista Brasileira de Ciência Avícola 2012 14: $275-282$.

Purswell JL, Luck BD, Davis JD. Effect of air deflectors on fan performance in tunnel-ventilated broiler houses with a dropped ceiling. Applied Engineering in Agriculture 2014; 30: 471-475.

Roberto JVB, Souza BB. Use of infrared thermography in veterinary medicine and animal production. Journal of Animal Behavior Biometeorology 2014; 2: 73-84.

Saaty TL. The analytic hierarchy process. McGraw-Hill Press, New York, NY, USA, 1980.

Sarica M, Yamak US, Boz MA. Effect of production systems on footpad dermatitis (FPD) levels among slow, medium and fast-growing broilers. European Poultry Science 2014; 78: 1-10.

Shepherd EM, Fairchild BD. Footpad dermatitis in poultry. Poultry Science 2010; 89: 2043-2051

Silva FAZ, Azevedo CAV. Comparison of means of agricultural experimentation data through different tests using the software Assistat. African Journal of Agricultural Research 2016; 11: 3527-3531.

Souza APO, Sans EC, Müller BR, Molento CFM. Broiler chicken welfare assessment in Globalgap certified and non-certified farms in Brazil. Animal Welfare 2015; 24: 45-54.

Taira K, Nagai T, Obi T, Takase K. Effect of litter moisture on the development of footpad dermatitis in broiler chickens. The Journal of Veterinary Medical Science 2014; 76: 583-586.

Thompson ML, Myers JE, Kriebel D. Prevalence odds ratio or prevalence ratio in the analysis of cross-sectional data: what is to be done? Occupational Environment Medicine 1998; 55: 272-277

Tuyttens F, Vanhonacker F, Verbeke W. Broiler production in Flanders, Belgium: Current situation and producers' opinions about animal welfare. World's Poultry Science Journal 2014; 70: 343-354.

Vassarstats. 2016. VassarStats - Website for Statistical Computation. Available at: http://vassarstats.net/ [Accessed Mar 2, 2016]. 